Łukasz Hadaś

Politechnika Poznańska

E-mail: lukasz.hadas@put.poznan.pl

Filip Karaśkiewicz

Politechnika Poznańska

E-mail: filip.karaskiewicz@ put.poznan.pl

Hubert Wojciechowski

Politechnika Poznańska

E-mail: hubert.wojciechowski@ put.poznan.pl

\title{
IDENTIFICATION AND CHARACTERISTIC OF NECESSARY EMPLOYEES' \\ COMPETENCES RESPONSIBLE FOR IMPLEMENTING ENGINEERING \\ CHANGES IN AUTOMOTIVE INDUSTRY
}

\begin{abstract}
Background: This chapter is devoted to the engineering changes and its requirements in employees' competences. The main objective of this research is to determine, which employees' competences are necessary for each workplace in every department. Secondary objective is to identify recommended positions for carrying out tasks in the departments in which implementation process of engineering changes is realised. Every competence also needs to be identified and characterized to determine what level of this competence is needed for a specific duty.
\end{abstract}

Methods: Basing on the in-depth interview with experts from different automotive companies, results from literature review and participant observation in few automotive enterprises let create a list of necessary employees' competences responsible for implementing engineering changes in automotive companies.

Results: The list of necessary employees' competences responsible for implementing engineering changes in automotive companies was developed. Each of the competences was allocated to the positions in every department engaged: engineering, logistics, production and quality. In the last stage of research work, all analyzed positions were linked to the list of tasks required for implementing engineering changes.

Conclusions: Project managers are provided with wider view and fuller information during the change management processes by using the list of necessary employees' competences 
responsible for implementing engineering changes in automotive companies. This list can lead to better assignment of employees to workstations and duties.

Keywords: employees' competences, engineering changes, automotive industry.

\section{INTRODUCTION TO THE COMPETENCES OF EMPLOYEES RESPONSIBLE FOR IMPLEMENTING ENGINEERING CHANGES IN THE AUTOMOTIVE INDUSTRY}

The implementation of engineering changes in enterprises of the automotive industry requires special competences and qualifications from employees. The specificity of the automotive industry is particularly evident in terms of timely deliveries, which must not only be delivered to the customer within a narrow period of time, but this specificity also applies to the quality of individual components, the method of packaging and transport, and many other requirements specified by customers in the form of a document CSR (Customer Specific Requirements). In order to meet customer requirements, enterprises are forced to constantly develop not only the technologies used in production, but also the competences and qualifications of employees. In literature there is a unification between core competences, assets, skills, capability and routine [Bonjour, Micaelli 2009, Fellin, Foss 2009, McDermott, Coates 2007]. A core competence can be used in whole production process as it is not one product related [McDermott and Coates 2007]. Due to the strong connection between the required competencies and qualifications of employees, the authors decided not to separate these two areas. Required competences from survey results [Spöttl 2017] shows that in Logistic 4.0 companies, employees need to be multi-tasking and be able to shape software to if necessary. Creating list of necessary competences is a subject of multiple research studies [Liszka, Klimkiewicz and Malinowski 2019, Strojna, Piotrowicz and Żywiec-Dąbrowska 2014].

There are many divisions and ways of grouping competences and qualifications in the literature, they can be divided into basic, cognitive, social, personal, executive, business, company and managerial [Filipowicz 2004] or the division may include threshold, key and optimal competences on basic and executive and on the main components of soft (behavioral) and hard (functional) competences [Oleksyn 2006]. Competences and qualifications are also discussed in the Regulation of the Minister of National Education of 7 February 2012 on the core curriculum for vocational education [Dz.U. 2012 poz. 184.], which describes the expected qualifications and competences that will be acquired in the teaching processes. Yet 55 
there is another division which divides competences into transferable and specific ones [Juchowicz 2014].

Competence is also defined in literature in many ways. Professional competence is the ability to perform activities in the profession in a manner consistent with the standards required for a given professional task [Nowacki 2004]. On the other hand, competences are described as a cognitive structure composed of specific skills, which is fuelled by knowledge and experience [Wiatrowski 2005]. Competences are knowledge, experience of abilities and skills [Kwiatkowski 2018]. Competences can be defined as a set of individual characteristics that predestine an individual for proactive adaptation in work or career [Fugate et al. 2004].

\section{RESEARCH METHODOLOGY}

The authors decided to compile a list of required competencies and qualifications of employees responsible for implementing production changes in the automotive industry based on several sources: the analysis of job offers, job descriptions and interviews with managers responsible for recruiting employees.

The results obtained in this way regarding the list of competences and qualifications were summarized and grouped into four departments in the enterprise (quality department, production department, logistics department and engineering department) actively participating in the process of implementing technical changes. In each of these departments a hierarchical pyramid was created, where each level is described by the name of the position and the required competences and qualifications for the given position (fig 1.).

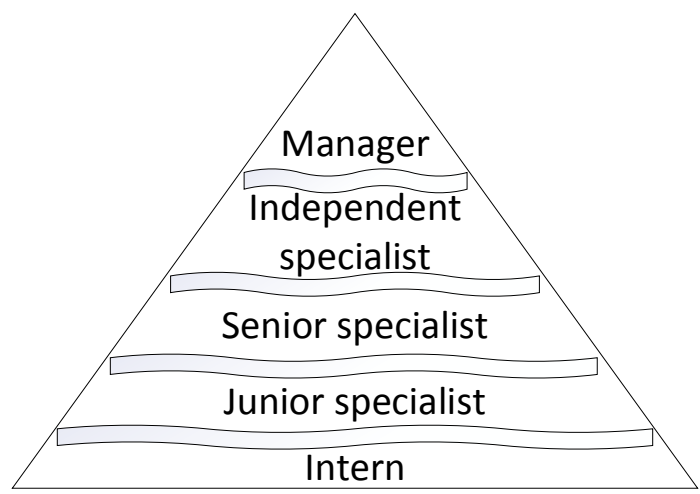

Fig. 1. "Pyramid" of job positions. Source: own work.

The "pyramid" of job positions is based on the assumption that all competences and qualifications below the analysed job position are required by that position. For example: a senior specialist must have the qualifications and competences of a young specialist and intern. When conducting research in enterprises, it was noticed that not all departments need 
to have all positions (see Fig. 1.), as well as some departments may have several different positions at one level (e.g. employee with a specialization), which will merge at a later stage in the pyramid. The concept of the research process was first to develop a preliminary list of competences and qualifications of employees responsible for implementing engineering changes based on their own knowledge and job offers. At a later stage, this list has been narrowed down by eliminating identical competences (described in job offers in various ways). Such prepared list was verified by managers and senior specialists from the automotive industry (from tier 1 suppliers, which work directly with OEM companies).

Managers and specialists verified the list of required competencies based on several years of experience in their own departments involved in the process of implementing engineering changes. Then, after obtaining feedback and available job descriptions, lists of competences and qualifications for each department were developed, along with the division into positions. In the last stage of work, all analyzed positions were linked to the list of tasks required for implementing engineering changes.

\section{LIST AND CHARACTERISTICS OF REQUIRED COMPETENCIES AND QUALIFICATIONS OF EMPLOYEES RESPONSIBLE FOR IMPLEMENTING ENGINEERING CHANGES IN AUTOMOTIVE COMPANIES}

\section{Engineering department - competences and qualifications}

As a result of the work, 16 key competences and qualifications were identified for the engineering department, divided into 4 positions:

- Independent specialist - key competences and qualifications:

○ 5-10 years' experience in manufacturing engineering,

○ Project Management skills,

○ Familiarity with Failure Mode and Effects Analysis (DFMEA/PFMEA),

○ Proven PLC programming skills.

- Senior specialist - key competences and qualifications:

- Ability to evaluate, plan, analyze and make viable decision in a JIT work environment to ensure efficiency and timely implementation,

- Excellent time and multiple project management skills and experience,

○ Geometric Dimensioning and Tolerancing (GD\&T),

○ Basic understanding of budgets and financial reporting.

- Junior specialist - key competences and qualifications: 
○ Engineering degree supported by a Mechanical/Electrical Technician background,

- Knowledge of tools and manual technical skills,

○ Ability to work independently without supervision.

- Intern - key competences and qualifications:

○ Knowledge of General Manufacturing practices/Lean Manufacturing/5S,

- Ability to use MS Excel on basic level,

○ Knowledge of Ergonomics,

○ Good English language written and verbal communication skills with fluency in other languages being an asset,

○ Strong communication and organizational skills.

The employees of this department carry out 26 different tasks in the process of implementing engineering changes. Each task from engineering department was linked to the recommended position level and presented in Table.

Table 1. Recommended position for carrying out tasks in the engineering department

\begin{tabular}{|c|c|}
\hline Task in the engineering department: & Recommended position: \\
\hline $\begin{array}{l}\text { Launching the procedure for implementing the engineering change. Asking for an opinion (assessment) } \\
\text { members of the team responsible for the product about launching the engineering change. }\end{array}$ & Independent specialist \\
\hline Preparing 3D model design & Independent specialist \\
\hline Changing the material from which the product is made & Independent specialist \\
\hline Changing the part number for production is given in the form of an engraver or a stamp & Independent specialist \\
\hline Update of the list of materials and components (BOM) used for the production of a given product & Junior specialist \\
\hline Updating the information on the label / sticker & Junior specialist \\
\hline Updating 2D documentation & Independent specialist \\
\hline Transfer of 2D documentation to all required departments for expressing opinions & Intern \\
\hline Rating of Customer Special Requirements (CSR) & Senior specialist \\
\hline Determining technological capabilities (machine feasibility) & Senior specialist \\
\hline Determining supplier capabilities (supplier feasibility) & Independent specialist \\
\hline Checking whether the introduced engineering change will affect the load of the machine park & Senior specialist \\
\hline Change of the machine/tools used for producing the product & Independent specialist \\
\hline Modification of the machine park/tools for the purpose of introducing a engineering change & $\begin{array}{l}\text { Manager decides, who will be } \\
\text { responsible for this task. } \\
\text { Decision is based on type of } \\
\text { engineering change. }\end{array}$ \\
\hline Changing the layout of machines on the production floor & Independent specialist \\
\hline Developing process sheet & Independent specialist \\
\hline Changing the way of packing and transporting products & Independent specialist \\
\hline Performing tests after the pilot batch & Independent specialist \\
\hline Development of the work instructions & Junior specialist \\
\hline $\begin{array}{l}\text { Significant change in labor intensity (analysis of demand for human resources, Methods Time } \\
\text { Measurement-MTM) }\end{array}$ & Manager \\
\hline Preparation and training of machines operators to work according to new rules and instructions & Junior specialist \\
\hline Updating the history of all existing changes (logs) saved and sending it to customer & Junior specialist \\
\hline Update of ANDON system settings (information exchange in production processes) & Junior specialist \\
\hline Update of production parameters (cycle, Takt time, lead time) & Junior specialist \\
\hline Preparation of work instructions for spare parts & Junior specialist \\
\hline Checking the production process in terms of performance and quality (Run \& Rate) & Independent specialist \\
\hline EDI upgrade for customer orders (Electronic Data Interchange) & Junior specialist \\
\hline
\end{tabular}


Source: own work.

The engineering department is the leader in the implementation process. The reason for it is that engineering department is responsible for designing and developing next steps in change management processes. That is the reason, why the largest number of tasks is carried out in engineering department.

\section{Logistics department - competences and qualifications}

As a result of the work, 21 key competences and qualifications were identified for the logistics department, divided into 5 positions:

- Manager - key competences and qualifications:

- A minimum of 5 Years Logistics/Production

- Independent specialist-key competences and qualifications:

- Good leadership and ability to manage professional multi-skilled resources as well as multi-task activities,

○ Knowledge of ISO16949 (formally QS9000/IS 9000 standards).

- Junior specialist (logistic) - key competences and qualifications:

- Master diploma or equivalent experience,

○ Strong organizational skills,

- Excellent time and multiple project management skills and experience,

- Ability to evaluate, plan, analyze and make viable decisions,

○ Knowledge of MRP Systems,

- Excellent computer skills - high level of proficiency in Windows, Excel and MS Office.

- Good English language, written, verbal and understanding skills with fluency in other languages being an asset,

○ Excellent interpersonal and communication skills.

- Junior specialist (warehouseman) - key competences and qualifications:

○ Forklift license,

- Familiar with use of material handling equipment,

- Familiarity with shipping and receiving requirements,

○ Organization and Inventory skills,

○ Supervisory skills,

○ Good interpersonal skills,

○ Good oral and written communication skills, 
○ 1-year experience.

- Intern - key competences and qualifications:

- Ensuring optimal flow of packaging entrusted with the assumption of cost reduction,

- The employee should contribute to his or her environment, in which honesty and justice are the standards and there are no discriminatory practices.

In the next stage of work each task from logistics department was linked to the recommended position level and presented in Table 2.

Table 2. Recommended position for carrying out tasks in the logistics department.

\begin{tabular}{|l|l|}
\hline \multicolumn{1}{|c|}{ Task in the logistics department: } & \multicolumn{1}{|c|}{$\begin{array}{c}\text { Recommended } \\
\text { position: }\end{array}$} \\
\hline $\begin{array}{l}\text { Checking the machine availability in terms of technology (machine capacity) and determining the required buffer } \\
\text { of parts }\end{array}$ & Independent specialist \\
\hline Registration of a new material supplier according to norm ISO9001 & Independent specialist \\
\hline Receival of materials and components & Junior specialist \\
\hline Updating the IMDS (International Material Data System) database & Independent specialist \\
\hline $\begin{array}{l}\text { The way of using the parts in stock buffer before the change in production (running change, stock scrap) - } \\
\text { assessment whether after the engineering change the inventory should be disposed of before the change, or it can } \\
\text { be used }\end{array}$ & Manager \\
\hline Determining the amount of parts in stock buffer before the change is implemented & Independent specialist \\
\hline Receival of components and materials for the trial series & Junior specialist \\
\hline $\begin{array}{l}\text { Change in the location of inventory (components, materials and finished products) in the warehouse (for parts } \\
\text { before and after engineering change) }\end{array}$ & Independent specialist \\
\hline $\begin{array}{l}\text { Change of the test / trial part number not released into the production process, usually in the form of a label - } \\
\text { packaging label }\end{array}$ & Independent specialist \\
\hline Change of destination for shipments of final products & Manager \\
\hline
\end{tabular}

Source: own work.

The logistics department is responsible mainly for operations with material handling. This includes receival new materials, delivery final products and taking to stock components and materials. The key task in Logistics department from engineering change management point of view is to provide availability of parts and creating stock buffer.

\section{Quality department - competences and qualifications}

As a result of the work, 12 key competences and qualifications were identified for the quality department, divided into 4 positions:

- Manager - key competences and qualifications:

○ Minimum of 8 years' experience in a direct role measuring automotive / aerospace components, including developing efficient CMM (Coordinate

Measuring Machine) programs for repeat measurement. First-hand knowledge of CMM machine software is required; 
○ Strong knowledge of GD\&T; significant experience in developing GD\&T for automotive / aerospace components;

- Deep understanding of Checking Fixture / Gauge Design, including standards for Gauge Designs and Approvals in an automotive OEM / Supplier environment;

○ Good understanding of SPC - Statistical Process Control. Knowledge of MiniTab is a plus but not necessary;

- Able to troubleshoot Gauges and CMM programs to identify and reduce sources of measurement error.

- Independent specialist - key competences and qualifications:

- Solid experience in automotive PPAP protocols and Measurement System Analysis rules under TS16949,

- Highly organized and disciplined, able to work independently and react quickly to high demand urgent situations when needed,

- An aptitude for teaching, coaching, and mentoring a wide range of people with a diverse set of skills; skilled at explaining complex issues to less technical people.

- Senior specialist - key competences and qualifications:

○ Post-secondary graduate in Mechanical Engineering / Engineering Technology,

○ Good knowledge of the full range of Measurement equipment, including Fixed and Portable CMM, Laser, White Light, Optical, etc., and the ability to determine optimum measurement solutions based on technical specifications and product applications.

- Intern - key competences and qualifications:

○ Demonstrated proficiency with Microsoft Office programs,

- Strong verbal and written communication, persistent and tactful in dealing with a variety of stakeholders.

In the next stage of work, each task from quality department was linked the recommended position level and presented in Table 3.

Table 3. Recommended position for carrying out tasks in the quality department.

\begin{tabular}{|l|l|}
\hline \multicolumn{1}{|c|}{ Task in the quality department: } & \multicolumn{1}{|c|}{ Recommended position: } \\
\hline PFD update (process flow diagram) & Intern \\
\hline
\end{tabular}




\begin{tabular}{|c|c|}
\hline $\begin{array}{l}\text { FMEA update (analysis of the types and effects of possible errors, Failure Mode and Effects Analysis - } \\
\text { FMEA) }\end{array}$ & Independent specialist \\
\hline Update of the control plan (Control Plan document) & Independent specialist \\
\hline Change / modification of controls and measuring devices & Independent specialist \\
\hline Checking the correctness of the selected system and measurement system analysis (MSA) & Independent specialist \\
\hline Change of the inspection plan on the supply control (frequency, type of control) & Independent specialist \\
\hline Change of instructions according to which the measurement of the product is to be made & Junior specialist \\
\hline Change of instructions on checking the visual aspects of the product & Junior specialist \\
\hline Control of special characteristics of the product (e.g. weight, functional dimension) & Independent specialist \\
\hline Changing patterns for error checking - error proofing samples (poka-yoke samples) & Independent specialist \\
\hline Validation tests / material certification (Design Validation Plan and Report - DVPR) & Senior specialist \\
\hline Report of visual inspection of parts produced after the change (Appearance Approval Report - AAR) & Independent specialist \\
\hline Part approval by the customer (Production Part Approval Process - PPAP) & Senior specialist \\
\hline $\begin{array}{l}\text { Changing the mailing label - whether the labelling of the product for shipment changes with an } \\
\text { engineering change or not }\end{array}$ & Junior specialist \\
\hline
\end{tabular}

Source: own work.

Employees of quality department with different levels of competence are involved in the implementation of engineering changes. Nevertheless, due to the importance of the required tasks, they are mainly independent and senior specialist positions.

\section{Production department - competences and qualifications}

As a result of the work, 64 key competences and qualifications were identified for the production department, divided into 11 positions:

- Manager (maintenance) - key competences and qualifications:

o Three (3) years related experience in a similar role with a Preventative Maintenance Program.

- Independent specialist (maintenance) - key competences and qualifications:

- Higher technical education or equivalent and 5 years of experience in the maintenance department,

○ Wide knowledge of mechanics and electrics,

○ Understanding budgets and financial reports at a basic level,

- The ability to evaluate, plan, analyze and make real decisions in the JIT work environment to ensure efficiency and timely implementation,

○ Excellent computer knowledge,

○ Supervisory skills,

- Excellent skills and experience in managing time and many projects

○ Good organizational skills, 
○ Good command of spoken and written English. Good knowledge of other languages will be an advantage,

○ Basic knowledge of labor law, including basic rules for calculating working hours, knowledge of human rights and internal codes.

- Senior specialist (maintenance) - key competences and qualifications:

○ Knowledge of issues related to pneumatics and hydraulics,

- Knowledge of issues related to metalwork,

- Ability to operate a milling machine, lathe,

○ TIG welding and electrode welding skills,

- Knowledge of metal and plastic properties,

- Knowledge of the construction of specific tools (adequate to the production process of specific company),

○ Skills of precision work with manual tools.

- Junior specialist (maintenance) - key competences and qualifications:

○ Knowledge of pneumatics and hydraulics,

○ Knowledge of motors and pumps,

○ Knowledge of electric and automation systems,

- Mechanical aptitude,

○ Excellent interpersonal and communication skills.

- Manager (production) - key competences and qualifications:

○ 3-7 years' experience in manufacturing engineering,

- Good leadership and ability to manage professional multi-skilled resources as well as multi-task activities.

- Independent specialist (production) - key competences and qualifications:

○ Proven PLC programming skills,

○ Master's degree supported by a Machines Building, Materials Engineering -

Production Engineering, Mechatronics, technician background,

○ Familiarity with Failure Mode and Effects Analysis (DFMEA / PFMEA),

- Project Management skills,

- Excellent time and multiple project management skills and experience,

- Ability to train less experience engineers,

- Value added input in business decisions,

- Team Player and able to work on own initiative, 
○ Strong communication and organizational skills.

- Senior specialist (production) - key competences and qualifications:

- Bachelor's degree supported by a Machines Building, Materials Engineering, Production Engineering, Mechatronics, technician background.

- Familiarity with Geometric Dimensioning and Tolerancing (GD\&T)

○ Ability to evaluate, plan, analyze and make viable decision in a JIT work environment to ensure efficiency and timely implementation

○ Basic understanding of budgets and financial reporting,

- Basic knowledge of Ergonomics,

- Basic knowledge of General Manufacturing practices / Lean Manufacturing / $5 \mathrm{~S}$,

○ Good time and several project management skills and some experience,

○ Good interpersonal and communication skills,

○ Good time management skills,

○ Good English language written and verbal communication skills.

- Junior specialist (production) - key competences and qualifications:

○ Basic knowledge of mathematics.

- Independent specialist (setters) - key competences and qualifications:

- Higher education in Production management or equivalent or five (5) years related manufacturing experience,

- Ability to evaluate, plan, analyze and make viable decision in a JIT work environment to ensure efficiency and timely implementation,

○ Good English language written and verbal communication skills with fluency in other languages being an asset,

○ Geometric dimensioning and tolerance skills,

○ Performing analyzes of failures and their effects,

○ Supervisory skills,

○ Excellent interpersonal and communication skills,

- Basic knowledge of Labor law including basic rules of working hours calculation, human rights, internal codes.

- Senior specialist (setters) - key competences and qualifications:

$\circ 5$ years of experience as a setter,

- Knowledge of ergonomics, 
○ Strong organizational skills,

○ Excellent computer skills.

- Intern (setters) - key competences and qualifications:

- Knowledge of specific machines (adequate to the production process of specific company),

$\circ$ Work on specific machines (adequate to the production process of specific company),

- Detail oriented,

○ Mechanical abilities,

○ Math skills,

○ Ability to work independently,

○ Good verbal and written communication skills.

In the last stage of work, all positions from production department were linked to the list of tasks required for implementing engineering changes from this department (table 4.).

Table 4. Recommended position for carrying out tasks in the production department

\begin{tabular}{|c|c|}
\hline Task in the production department: & Recommended position: \\
\hline $\begin{array}{l}\text { Updating the plan of machine and tooling inspections (Preventive Maintenance } \\
\text { Schedule) }\end{array}$ & $\begin{array}{l}\text { Production: - } \\
\text { Maintenance: Junior specialist } \\
\text { Setters: - }\end{array}$ \\
\hline Implementation of assumptions regarding the preparation of a safety stock & $\begin{array}{l}\text { Production: Senior specialist } \\
\text { Maintenance: - } \\
\text { Setters: Junior specialist }\end{array}$ \\
\hline
\end{tabular}

Source: own work.

The production department requires employees with different qualifications, but there are only several specialists directly involved in the implementation process of engineering changes.

\section{CONCLUSIVE REMARKS}

Engineering changes implementation process is a complex activity that involves experts from all across the company. It is important that each action is clearly stated and have resource assigned. To finalize whole process in time and cost-efficient way resources should have certain skills and experience. In most cases each Engineering Change has a clear deadline - it might be internal, stated by company's management, or external forced by company's customer. Both variants keep strong pressure on implementation team creating 
possibilities of committing unwanted mistakes. In automotive industry fulfilling customer needs is usually most important for suppliers, so managers are doing their best to keep clients satisfied. Due to this there is a strong need of assigning Engineering Changes Leader to coordinate team and control timing. Furthermore, it is worth to say that leader in this case is a role not a position. It can be a manager or a specialist, not necessarily familiar with technical aspects of change.

\section{ACKNOWLEDGMENTS}

This chapter was funded by the Poznan University of Technology, Faculty of Engineering Management [project number: 11/140/SBAD/4168].

\section{REFERENCES}

Bonjour, E. and Micaelli, J.P., 2009. Design core competence diagnosis: a case from the automotive industry. IEEE Transactions on Engineering Management, 57(2), pp.323-337, DOI: 10.1109/TEM.2009.2036838

McDermott C., Coates T., Managing competencies in breakthrough product development: A comparative study of two material processing projects, IEEE Trans. Eng. Manage, vol. 54, no. 2, pp. 340-350, May 2007, DOI: 10.1109/TEM.2007.893994

Classification of professions and specialties, Labor Market Department 2014,

Filipowicz, Grzegorz., 2004, Zarządzanie kompetencjami zawodowymi [Professional competence management]. Polskie Wydaw. Ekonomiczne.

Fugate, Mel, Angelo J. Kinicki, and Blake E. Ashforth., 2004, "Employability: A psychosocial construct, its dimensions, and applications." Journal of Vocational behavior 65.1, 14-38, DOI: 10.1016/j.jvb.2003.10.005

Kwiatkowski, S.M., 2018, Kompetencje przyszłości [Competences of the future], Fundacja Rozwoju Systemu Edukacji, Warszawa.

Juchnowicz M., 2014, Sektorowe badania podaży i popytu na kwalifikacje i kompetencje [Sectoral research on the supply and demand for qualifications and competences]. Education of Economists \& Managers/Edukacja Ekonomistow i Menedzerow 32.2.

Liszka, K., Klimkiewicz, K. and Malinowski, P., 2019. Polish Foundry Engineer with Regard to Changes Carried by the Industry 4.0. Archives of Foundry Engineering.

Nowacki, T. W., 2004, Leksykon pedagogiki pracy [Lexicon of labor pedagogy], Wyd. Instytut Technologii Eksploatacji, Radom. 
Oleksyn T., 2006, Zarządzanie kompetencjami teoria i praktyka [Competency management theory and practice], Oficyna Ekonomiczna, Kraków, s. 99.

Rozporządzenie Ministra Edukacji Narodowej z dnia 7 lutego 2012 r. w sprawie podstawy programowej kształcenia w zawodach [Regulation of the Minister of National Education of 7 February 2012 on the core curriculum for vocational education]

Spöttl G., 2017, November. Development of "Industry 4.0"! - Are Skilled Workers and SemiEngineers the Losers?. In 2017 7th World Engineering Education Forum (WEEF) (pp. 851-856). IEEE.

Felin T., Foss N.J., 2009, Organizational routines and capabilities: Historical drift and a course-correction toward microfoundations, Scandinavian J. Manage., vol. 25, no. 2, pp. 133-145, 2009, DOI: 10.1016/j.scaman.2009.02.003

Wiatrowski, Zygmunt., 2005, Podstawy pedagogiki pracy [Fundamentals of labor pedagogy]. Wydawnictwo Akademii Bygdoskiej im. Kazimierza Wielkiego. 